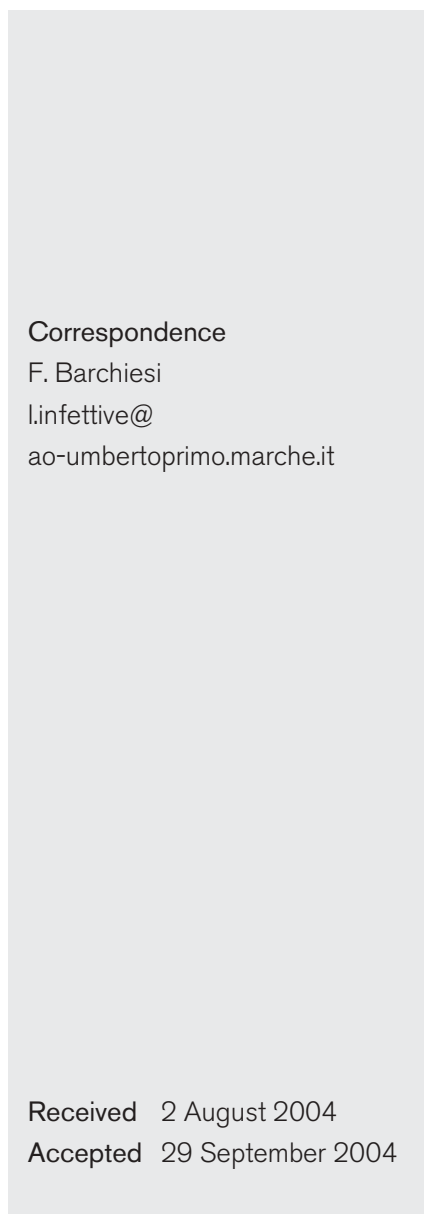

\section{Genotypic variation and antifungal susceptibilities of Candida pelliculosa clinical isolates}

\author{
F. Barchiesi, ${ }^{1}$ A. M. Tortorano, ${ }^{2}$ L. Falconi Di Francesco, ${ }^{1}$ A. Rigoni, ${ }^{2}$ \\ A. Giacometti, ${ }^{1}$ E. Spreghini, ${ }^{1}$ G. Scalise ${ }^{1}$ and M. A. Viviani ${ }^{2}$ \\ ${ }^{1}$ Istituto di Malattie Infettive e Medicina Pubblica, Università Politecnica delle Marche, Azienda \\ Ospedaliera Umberto I $^{\circ}$, Via Conca, 60020, Torrette di Ancona, Ancona, Italy \\ ${ }^{2}$ Istituto di Igiene e Medicina Preventiva, Università degli Studi di Milano IRCCS, Ospedale Maggiore di \\ Milano, Italy
}

\begin{abstract}
At the Istituto Ricovero Cura Carattere Scientifico, Ospedale Maggiore di Milano, Italy, Candida pelliculosa accounted for 3.3 and $4.4 \%$ of all Candida species other than Candida albicans collected during 1996 and 1998, respectively. Genetic variability was investigated by electrophoretic karyotyping and inter-repeat PCR, and the susceptibility to five antifungal agents of 46 strains isolated from 37 patients during these 2 years was determined. Combination of the two typing methods yielded 14 different DNA types. Although the majority of DNA types were randomly distributed among different units, one DNA type was significantly more common in patients hospitalized in a given unit compared with those from other wards $(P=0.034)$, whereas another DNA type was more frequently isolated in patients hospitalized during 1996 than in those hospitalized during $1998(P=0.002)$. Fluconazole, itraconazole and posaconazole $\mathrm{MIC}_{90}$ values were 16,1 and $4 \mu \mathrm{g} \mathrm{ml}^{-1}$, respectively. All isolates but three were susceptible in vitro to flucytosine. All isolates were susceptible in vitro to amphotericin $\mathrm{B}$. These data suggest that there are possible relationships among strains of C. pelliculosa, wards and time of isolation. Amphotericin B seems to be the optimal drug therapy in infections due to this yeast species.
\end{abstract}

\section{INTRODUCTION}

The risk of opportunistic infections is greatly increased in patients who are severely immunocompromised. Although Candida albicans is the organism most often associated with serious fungal infections, other Candida species have emerged as clinically important pathogens associated with opportunistic infections (Hazen, 1995).

Candida pelliculosa (teleomorph Pichia anomala) is a yeast frequently found in various fruits, tree exudates, soil, vegetables and other organic compounds (Kwon-Chung \& Bennett, 1992). It has occasionally been reported as causative agent of fungaemia in both immunocompetent and immunocompromised patients, including those with AIDS (Alter \& Farley, 1994; Goss et al., 1994; Haron et al., 1988; Hirasaki et al., 1992; Klein et al., 1988; Kunova et al., 1996; Munoz et al., 1989; Neumeister et al., 1992; Salesa et al., 1991; Sekhon et al., 1992; Taylor et al., 1994). Recently, Thuler et al. (1997) described an outbreak of 24 cases of infection due to $C$. pelliculosa in an oncological hospital in Rio de Janeiro, Brazil.

Abbreviations: EK, electrophoretic karyotyping; ICU, intensive care unit; IR-PCR, inter-repeat PCR; RAPD, randomly amplified polymorphic DNA; RFLP, restriction fragment length polymorphism.
The majority of these cases were related to the presence of both central and peripheral venous catheters. C. pelliculosa has also been reported as a causative agent of nosocomial cerebral ventriculitis in low-birth-weight neonates, endocarditis in an intravenous drug abuser and urinary tract infection in a renal transplant recipient (Salesa et al., 1991; Murphy et al., 1986; Nohinek et al., 1987; Qadri et al., 1988). While amphotericin $\mathrm{B}$, alone or in association with flucytosine, seems to be effective against $C$. pelliculosa infections, the role of fluconazole is uncertain (Hazen, 1995; Alter \& Farley 1994; Hirasaki et al., 1992; Klein et al., 1988; Kunova et al., 1996). In a recent study carried out to analyse the antifungal susceptibility of clinical isolates belonging to seven uncommon species of Candida, of 15 C. pelliculosa strains, eight were shown to be fluconazole resistant, six were itraconazole and ketoconazole resistant and one was flucytosine resistant (Barchiesi et al., 1999). This finding is particularly worrying, since, besides amphotericin $\mathrm{B}$, few therapeutic options are currently effective against this fungal infection.

At the Istituto Ricovero Cura Carattere Scientifico (IRCCS), Ospedale Maggiore di Milano, Italy, C. pelliculosa accounted for 3.3 and $4.4 \%$ of all Candida species other than C. albicans collected during 1996 and 1998, respectively. Most of these 
strains were isolated from the respiratory tracts of intubated patients hospitalized in intensive care units (ICUs).

In an effort to understand the epidemiology of this high colonization rate, we investigated the genetic variability and the susceptibility profiles of 46 clinical isolates of $C$. pelliculosa isolated over this 2-year period.

\section{METHODS}

Sources of isolates. A total of 46 clinical isolates of C. pelliculosa were isolated from 37 patients hospitalized in seven different wards, namely three ICUs, three surgery departments and one haematology department of the IRCCS, Ospedale Maggiore di Milano, or submitted to bronchoscopy in a bronchoscopy service (Table 1). Eleven strains were isolated during 1996 and 35 strains were isolated during 1998. Thirty-six strains were isolated from the respiratory tract, seven strains from the gastrointestinal tract and three strains from the genitourinary tract. Yeasts were identified at the species level by morphological and biochemical methods (ID32C; bioMérieux) and stored in sterile water at room temperature.

Molecular typing. Yeast isolates from $48-72 \mathrm{~h}$ culture plates were suspended in $20 \mathrm{ml}$ yeast peptone glucose $(1 \%$ yeast extract, $2 \%$ glucose, $2 \%$ Bacto-Peptone) and incubated at $35^{\circ} \mathrm{C}$ with agitation for $24 \mathrm{~h}$. For electrophoretic karyotyping (EK), plugs containing yeast chromosomal DNA were prepared as described previously (Barchiesi et al., 1995). For inter-repeat PCR (IR-PCR), yeast genomic DNAs were extracted as described by Scherer \& Stevens (1987).

For EK, chromosomes of $C$. pelliculosa were resolved with a contourclamped homogeneous electric-field system (CHEF DRII; Bio-Rad) through $1 \%$ SeaKem Gold agarose (FMC Bioproducts) in $0.5 \times \mathrm{TBE}$ (0.45 M Tris/ $\mathrm{HCl} \mathrm{pH} 8 \cdot 0,0 \cdot 44 \mathrm{M}$ boric acid, $10 \mathrm{mM}$ EDTA) at $14{ }^{\circ} \mathrm{C}$. Electrophoresis was performed at $4 \mathrm{~V} \mathrm{~cm}^{-1}$ for $45 \mathrm{~h}$ during which the switch time ramped from 30 to $300 \mathrm{~s}$, and for a further $6 \mathrm{~h}$ during which the switch time ramped from 420 to 900 s. A Saccharomyces cerevisiae marker (Bio-Rad) was used as a DNA size standard.

For IR-PCR, strains were fingerprinted with the eukaryotic telomeric repeat-like primer 5'-TAGGGTAGGGTAGGGTAGGG-3' (TELO 2), described by van Belkum et al. (1994). IR-PCR reaction mixtures consisted of $10 \mathrm{ng}$ genomic DNA, 50 pmol primer, $0.2 \mathrm{mM}$ each dNTP, $2.5 \mathrm{mM} \mathrm{MgCl}_{2}$ and $2.5 \mathrm{U}$ Taq DNA polymerase (Promega) in a final volume of $50 \mu \mathrm{l}$ buffer provided by the manufacturer. PCR was performed using a Thermolyne Temp-Tronic thermal cycler (Barnstead/Thermolyne) for 40 cycles of $1 \mathrm{~min}$ at $94{ }^{\circ} \mathrm{C}, 2 \mathrm{~min}$ at $52^{\circ} \mathrm{C}$ and $3 \mathrm{~min}$ at $72{ }^{\circ} \mathrm{C}$. Electrophoresis was performed in $0.8 \%$ agarose gels in $1 \times$ TBE buffer at $30 \mathrm{~V}$ overnight. HindIII-digested phage $\lambda$ DNA (BioRad) was used as a size marker.

Ethidium-bromide-stained gels were photographed under UV light. Prior to the computer-assisted analysis described below, patterns generated from the different typing methods were compared by visual inspection. For computer-assisted analysis, ethidium-bromide-stained gels were visualized under UV light in a GEL DOC 1000 scanner (BioRad) connected to Molecular Analyst Fingerprinting software (BioRad). Patterns were normalized by equating to molecular size markers. Band positions were automatically identified and Dice coefficients of similarity were determined for each pair of strains, generating a matrix of similarity. Dendrograms based on the similarity coefficients were then generated by the unweighted pair-group method of average linkage (Sneath, 1973). Two given strains were placed into the same DNA type group when their coefficient of similarity was $\geqslant 90 \%$ and into different DNA type groups when their coefficient of similarity was $<90 \%$.

Antifungal susceptibility. Fluconazole, itraconazole, posaconazole, flucytosine and amphotericin B MICs were determined using a broth microdilution procedure following the guidelines approved by the NCCLS (2002). Testing was performed in RPMI 1640 (Sigma Chemi$\mathrm{cal}$ ). Posaconazole and amphotericin B MIC determinations were also performed in Antibiotic Medium 3 (Difco Laboratories). Candida parapsilosis ATCC 22019 was used as a control strain.

Statistics. The distribution of types among the DNA fingerprinting groups were analysed using the $\chi^{2}$ test. A value of $P<0.05$ was considered statistically significant.

\section{RESULTS}

\section{Molecular typing}

Under our electrophoretic conditions, EK revealed six to eight bands (chromosomes) ranging in size from 990 to approximately $2700 \mathrm{kbp}$ (Fig. 1a). CHEF patterns revealed two to four bands in the high-molecular-mass region of $>2000 \mathrm{kbp}$, two to three bands in the region of $1800-1300$ $\mathrm{kbp}$ and one to two bands in the region of $<1300 \mathrm{kbp}$. Good agreement was noted between visual and computer-assisted identification of EKs. Overall, analysis of the 46 clinical isolates of $C$. pelliculosa revealed eight distinguishable DNA types (A-H; Table 1). DNA type A accounted for 33 of 46 isolates, DNA type $\mathrm{B}$ for 6 of 46 isolates and DNA type $\mathrm{C}$ for 2 of 46 isolates, whereas the remaining five isolates were each assigned to a unique DNA type (Fig. 1b).

IR-PCR produced eight distinct DNA types (1-8; Fig. 2a, b). DNA type 1 accounted for $14 / 46$ isolates with similarity coefficients ranging from 90.2 to $100 \%$, DNA type 4 accounted for $9 / 46$ isolates with similarity coefficients ranging from 92.3 to $100 \%$, DNA type 5 accounted for $8 / 46$ isolates with similarity coefficients ranging from $97 \cdot 2$ to $100 \%$ and DNA type 7 accounted for 6/46 isolates with coefficient of similarities ranging from $91 \cdot 1$ to $100 \%$. DNA types 2 and 6 contained three isolates each, DNA type 3 two isolates, while DNA type 8 contained only one isolate (Fig. $2 \mathrm{~b})$. In general, multiple isolates assigned to DNA type A by EK were assigned to distinct DNA types by IR-PCR, while all isolates assigned to DNA type B by EK were assigned to a unique DNA type by IR-PCR (DNA type 7; Table 1). During the study, the reproducibility of this typing method was assessed by preparation of DNA from the same isolate and amplification on two to four different occasions. Although the bands produced were sometimes less intense, their presence (or absence) and overall position were highly consistent.

The combination of the two typing methods, EK and IRPCR, yielded 14 different DNA types among the 46 clinical isolates of C. pelliculosa (Table 1). DNA type A1 was the most common (14 strains from 11 patients). DNA type A4 was significantly more common in patients hospitalized in the ICU ward compared with those from other wards: $4 / 9$ patients compared with $2 / 28$ patients, respectively $(P=0 \cdot 034)$. DNA type B7, which was recovered from six individuals belonging to three wards, was more frequently isolated in patients hospitalized during 1996 than in those 
Table 1. DNA types of the 46 clinical isolates of C. pelliculosa

NSICU, Neurosurgical ICU; He, haematology department; BU, bronchoscopy unit; SICU, surgical ICU; S1, surgery department no. 1; S2, surgery department no. 2; LTU, liver transplantation unit; BAS, bronchoaspirate; BAL, bronchoalveolar lavage. Dates are given in the form day/month/year.

\begin{tabular}{|c|c|c|c|c|c|c|}
\hline \multirow[t]{2}{*}{ Patient } & \multirow[t]{2}{*}{ Ward } & \multirow[t]{2}{*}{ Isolate } & \multirow[t]{2}{*}{ Date of isolation } & \multirow[t]{2}{*}{ Source of isolation } & \multicolumn{2}{|c|}{$\begin{array}{c}\text { DNA type } \\
\text { determined by: }\end{array}$} \\
\hline & & & & & EK & IR-PCR \\
\hline 1 & NSICU & 1 & $26 / 01 / 1996$ & Urine & B & 7 \\
\hline 2 & NSICU & 2 & $12 / 02 / 1996$ & BAS & B & 7 \\
\hline 3 & NSICU & 3 & $14 / 02 / 1996$ & BAS & B & 7 \\
\hline 4 & NSICU & 4 & $17 / 02 / 1996$ & BAS & A & 5 \\
\hline 5 & NSICU & 5 & 05/02/1998 & Urine & $\mathrm{C}$ & 5 \\
\hline 6 & NSICU & 6 & 07/02/1998 & BAS & A & 1 \\
\hline 7 & NSICU & 7 & $18 / 02 / 1998$ & BAS & $\mathrm{F}$ & 2 \\
\hline 8 & NSICU & 8 & $21 / 02 / 1998$ & BAS & A & 1 \\
\hline 9 & NSICU & 9 & $23 / 021998$ & BAS & A & 1 \\
\hline 10 & NSICU & 10 & $23 / 03 / 1998$ & BAS & A & 1 \\
\hline 11 & NSICU & 11 & 08/04/1998 & BAS & A & 1 \\
\hline \multirow[t]{2}{*}{12} & NSICU & $12 \mathrm{a}$ & $16 / 04 / 1998$ & BAS & A & 6 \\
\hline & & $12 b$ & $17 / 04 / 1998$ & BAS & A & 6 \\
\hline 13 & NSICU & 13 & $17 / 04 / 1998$ & BAs & A & 2 \\
\hline \multirow[t]{2}{*}{14} & NSICU & $14 \mathrm{a}$ & $23 / 04 / 1998$ & BAS & A & 4 \\
\hline & & $14 \mathrm{~b}$ & $24 / 04 / 1998$ & BAS & A & 4 \\
\hline 15 & NSICU & 15 & $23 / 05 / 1998$ & BAL & $\mathrm{E}$ & 5 \\
\hline 16 & ICU & 16 & 05/03/1996 & Oral secretion & $\mathrm{B}$ & 7 \\
\hline \multirow[t]{3}{*}{17} & ICU & $17 \mathrm{a}$ & $12 / 04 / 1996$ & BAS & $\mathrm{C}$ & 6 \\
\hline & & $17 \mathrm{~b}$ & 06/05/1996 & Vaginal secretion & A & 1 \\
\hline & & $17 \mathrm{c}$ & 06/05/1996 & Stool & A & 1 \\
\hline 18 & ICU & 18 & 05/02/1998 & Oral secretion & A & 3 \\
\hline 19 & ICU & 19 & $18 / 02 / 1998$ & BAS & A & 1 \\
\hline \multirow[t]{3}{*}{20} & ICU & $20 \mathrm{a}$ & 09/03/1998 & BAS & A & 4 \\
\hline & & $20 \mathrm{~b}$ & $13 / 03 / 1998$ & BAS & G & 5 \\
\hline & & $20 \mathrm{c}$ & $16 / 03 / 1998$ & BAS & A & 4 \\
\hline 21 & ICU & 21 & $16 / 03 / 1998$ & BAS & A & 2 \\
\hline 22 & ICU & 22 & $16 / 03 / 1998$ & Oral secretion & A & 4 \\
\hline 23 & ICU & 23 & $30 / 03 / 1998$ & BAS & A & 4 \\
\hline 24 & ICU & 24 & 03/04/1998 & BAS & A & 4 \\
\hline \multirow[t]{2}{*}{25} & He-BU & $25 a$ & $13 / 03 / 1998$ & BAS & A & 1 \\
\hline & & $25 b$ & $13 / 03 / 1998$ & BAL & A & 1 \\
\hline 26 & He-BU & 26 & 08/05/1998 & BAS & A & 5 \\
\hline 27 & $\mathrm{BU}$ & 27 & 03/06/1998 & BAS & A & 1 \\
\hline 28 & $\mathrm{BU}$ & 28 & $22 / 06 / 1998$ & BAS & A & 1 \\
\hline 29 & $\mathrm{BU}$ & 29 & 01/07/1998 & BAS & A & 1 \\
\hline 30 & SICU & 30 & 02/01/1996 & BAS & $\mathrm{B}$ & 7 \\
\hline 31 & SICU & 31 & $28 / 01 / 1998$ & BAS & A & 4 \\
\hline 32 & SICU & 32 & $10 / 04 / 1998$ & BAS & B & 7 \\
\hline 33 & $\mathrm{He}$ & 33 & $13 / 03 / 1998$ & BAL & A & 1 \\
\hline \multirow[t]{3}{*}{34} & $\mathrm{He}$ & $34 \mathrm{a}$ & $18 / 03 / 1998$ & Bile & A & 5 \\
\hline & & $34 \mathrm{~b}$ & $28 / 03 / 1998$ & Bile & A & 5 \\
\hline & & $34 \mathrm{c}$ & $25 / 05 / 1998$ & Bile & A & 5 \\
\hline 35 & S1 & 35 & 08/01/1996 & BAS & $\mathrm{H}$ & 8 \\
\hline 36 & S2 & 36 & 08/01/1996 & BAS & A & 3 \\
\hline 37 & LTU & 37 & 01/01/1998 & BAS & $\mathrm{D}$ & 4 \\
\hline
\end{tabular}


(a)

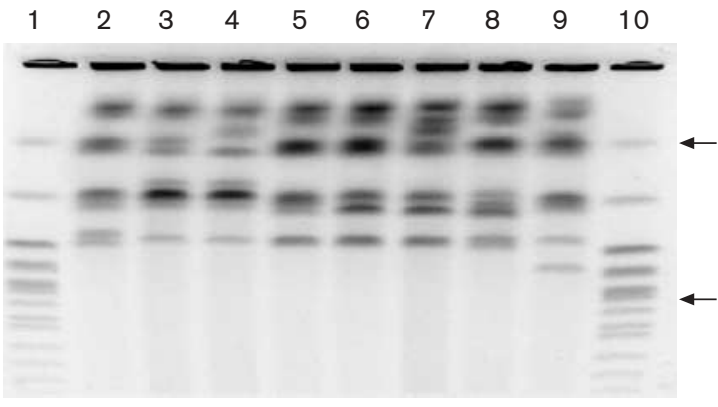

(b)

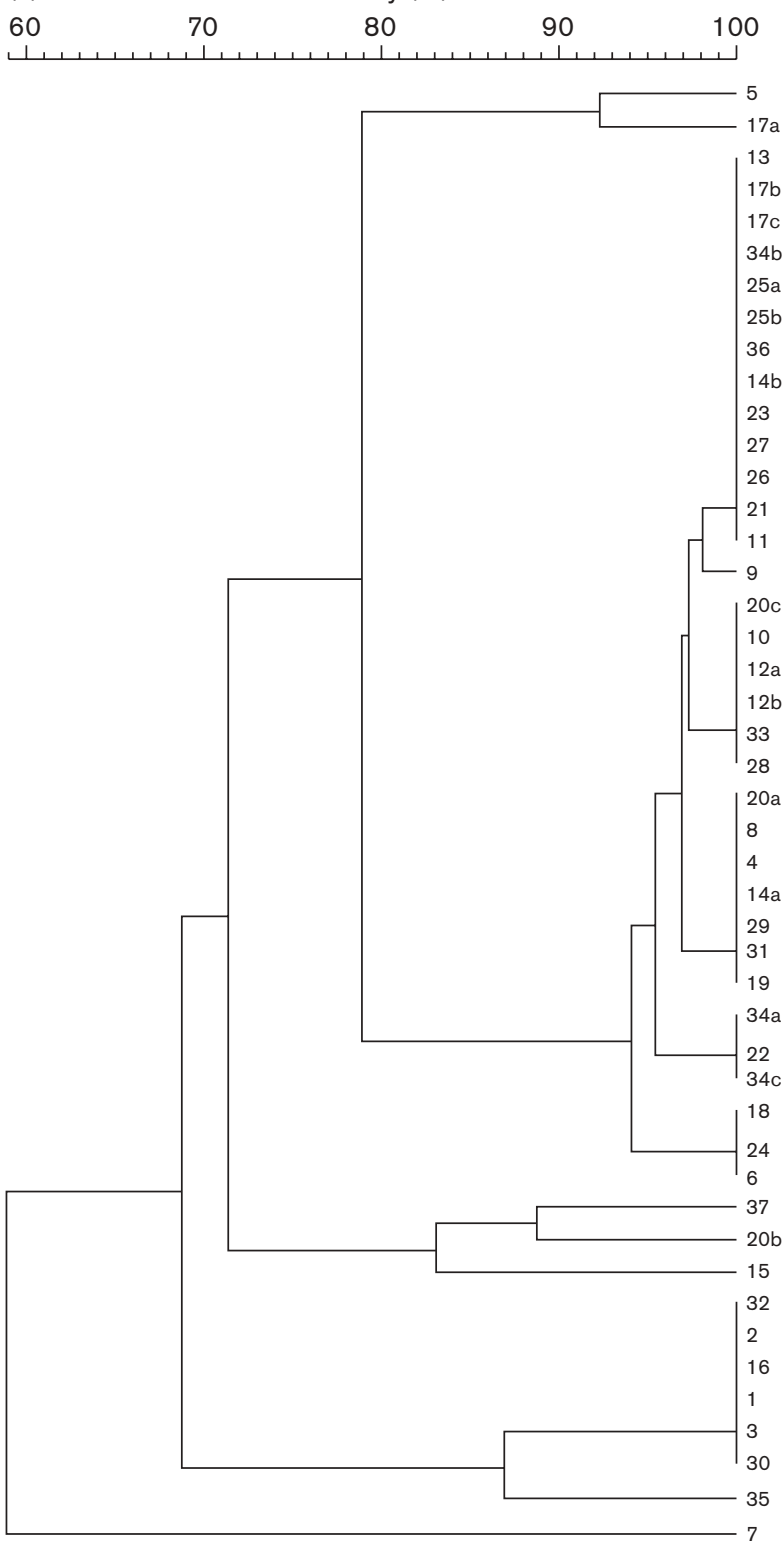

Fig. 1. (a) Representative DNA types of $C$. pelliculosa obtained by EK. Lanes 1 and 10, S. cerevisiae chromosome DNA size standards with lower and upper arrows indicating 825 and $2200 \mathrm{kbp}$, respectively; lanes 2-9, DNA types $A, B, H, C, G, D, E$ and $F$, respectively. (b) Dendrogram generated from the Dice coefficients computed from the EK patterns for 46 clinical isolates of $C$. pelliculosa. Isolates are listed in Table 1.
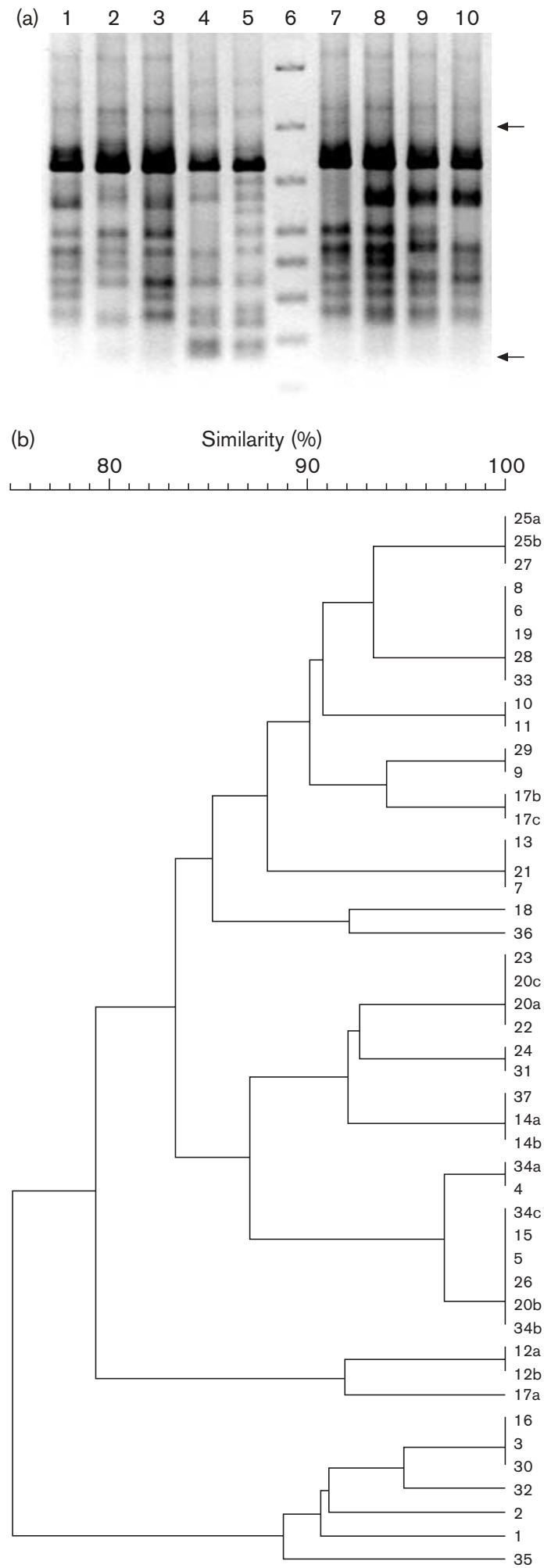

Fig. 2. (a) Representative DNA types of $C$. pelliculosa obtained by IRPCR. Lanes 1-3, DNA types 3, 4 and 5, respectively; lanes 4 and 5, DNA type 7; lane 6, DNA size standard with lower and upper arrows indicating 200 and 1000 bp fragments, respectively; lane 7, DNA type 6; lanes 8-10, DNA type 1. (b) Dendrogram generated from the Dice coefficients computed from the IR-PCR patterns for 46 clinical isolates of $\mathrm{C}$. pelliculosa. Isolates are listed in Table 1. 
hospitalized during 1998: 5/9 patients compared with $1 / 28$ patients, respectively $(P=0.002)$. DNA type A1 was more commonly isolated in patients hospitalized during 1998 than in those hospitalized in 1996, although the difference was not statistically significant: $11 / 28$ patients compared with $1 / 9$ patients, respectively $(P=0 \cdot 245)$. Among the six patients with multiple isolations over time, four were shown to be colonized by a single DNA type specific to each patient, while the other two were colonized by two different DNA types. In particular, patient 17 was shown to be infected, although in a different body location, with a new DNA type, while patient 20 was shown to be colonized with a mixed population of $C$. pelliculosa.

\section{Antifungal susceptibility}

Antifungal susceptibility patterns are shown in Table 2. With the exception of flucytosine, a narrow range was observed for all antifungal agents. Two isolates recovered from the same patient were shown to be resistant to flucytosine (MIC 32 and $\left.64 \mu \mathrm{g} \mathrm{ml}^{-1}\right)$. MIC $_{90}$ values were $16,1,4,0 \cdot 06$ and $1 \mu \mathrm{g} \mathrm{ml}^{-1}$ for fluconazole, itraconazole, posaconazole, flucytosine and amphotericin B, respectively.

\section{DISCUSSION}

In this study, two molecular methods directed at different targets of genomic DNA were used for typing clinical isolates of C. pelliculosa. In the last few years, pulsed-field gel electrophoresis analysis has been extensively applied to a large variety of clinical isolates belonging to different species of Candida and to other yeast genera (Pfaller, 1994). To our knowledge, this is the first study in which this typing procedure has been utilized to analyse C. pelliculosa clinical isolates. Although at the beginning of the study we experimented with several electrophoresis conditions against a

Table 2. In vitro activity of five antifungal agents against 46 clinical isolates of C. pelliculosa

$\mathrm{MIC}_{50}$ and $\mathrm{MIC}_{90}$ respectively represent the MIC at which 50 and $90 \%$ of the isolates are inhibited.

\begin{tabular}{|llccc|}
\hline Antifungal agent & \multirow{2}{*}{ Medium } & \multicolumn{3}{c|}{ MIC $\left(\boldsymbol{\mu g ~ m l}^{-1}\right)$} \\
\cline { 3 - 5 } & & MIC $_{\mathbf{5 0}}$ & MIC $_{\mathbf{9 0}}$ & Range \\
\hline Fluconazole & RPMI 1640 & 16 & 16 & $4-64$ \\
Itraconazole & RPMI 1640 & 1 & 1 & $0 \cdot 25-2$ \\
Posaconazole & RPMI 1640 & 2 & 4 & $1-8$ \\
& AM3 & 1 & 4 & $0 \cdot 5-8$ \\
Flucytosine & RPMI 1640 & $0 \cdot 06$ & $0 \cdot 06$ & $0 \cdot 06-64$ \\
Amphotericin B & RPMI 1640 & 0.5 & 1 & $0 \cdot 06-1$ \\
& AM3 & $0 \cdot 25$ & 0.5 & $0 \cdot 125-1$ \\
\hline
\end{tabular}

selected number of clinical isolates, we did not find one that was able to resolve the same number of bands as the method described here.

Previous studies have suggested that the use of a combination of different molecular typing methods may help to discriminate isolates belonging to the same species (Pfaller, 1994). Therefore, additional molecular typing methods - restriction fragment length polymorphism (RFLP) analysis and two PCR-based methods, namely randomly amplified polymorphic DNA (RAPD) and IR-PCR - were initially used to analyse $14 \mathrm{C}$. pelliculosa isolates showing variable DNA profiles by EK (data not shown). RFLP did not produce useful results because all 14 selected isolates of $C$. pelliculosa showed a unique DNA profile, depending on the enzyme utilized for the single digest (EcoRI, BamHI and HindIII). Similarly, RAPD performed with four primers [RP2, SOY and RP 4/2 (Lehmann et al., 1992) and M13 (Vassart et al., 1985)] was unsuccessful. In contrast, IR-PCR performed with primer TELO 2 showed high discriminatory power in analysis of the selected isolates. Therefore, IR-PCR performed with this primer was used for typing all 46 isolates and produced eight distinct DNA types $(1-8)$. This telomeric repeat-like primer was previously shown to be successful when strain relatedness among C. albicans isolates was investigated (van Belkum et al., 1994).

The combination of EK and IR-PCR enabled us to differentiate 14 DNA types for C. pelliculosa. Thus, despite the restricted geographical area of strain origin, a degree of heterogeneity of C. pelliculosa isolates was shown by these two typing methods.

In the patients studied, colonization by either one or multiple DNA types of C. pelliculosa occurred. Out of the six patients from whom more than one isolate of C. pelliculosa was typed (patients 12, 14, 17, 20, 25 and 34), two were colonized by different DNA types (patients 17 and 20) and four patients carried the same DNA type in sequential samples from the same body site. In particular, one patient (patient 34) was shown to be persistently colonized by the DNA type A5, as it was isolated from three bile samples collected during a 70day period.

One DNA type was prevalent in each of the two years studied. During 1996, DNA type B7 was identified in 5/9 patients hospitalized in three different ICUs and, during 1998, DNA type A1 was identified in 11/28 patients hospitalized in three different wards. In addition, prevalence of one DNA type was observed in one ward. DNA type A4 was isolated from four patients $(20,22,23$ and 24) hospitalized in an ICU during a 25-day period and DNA type A1 was isolated from the bronchial secretions of five patients $(6,8,9,10$ and 11) from a neurosurgical ICU during a 2 -month period (FebruaryApril 1998). DNA type A1 was also isolated from bronchial secretions or bronchoalveolar lavage of five patients examined in a bronchoscopy unit during an overlapping period (March-July 1998). These results suggest a possible clonal origin of the colonization. Cultures of catheters, broncho- 
scopes, gloves and other devices used in the units did not grow C. pelliculosa and a possible source of colonization was not demonstrated.

In vitro testing showed a poor susceptibility of $C$. pelliculosa strains to azole compounds, confirming previously reported data (Barchiesi et al., 1999). Susceptibility to amphotericin B was demonstrated with all of the isolates, regardless of the culture medium used for the in vitro testing. Flucytosine resistance was detected in only three isolates, belonging to two distinct DNA types (MIC 32-64 $\mu \mathrm{g} \mathrm{ml}^{-1}$ ). All of these strains were isolated from a single patient (patient 17) hospitalized in an ICU for polytrauma, who, as far as was known, had not previously received antifungal agents. The occurrence of fungal growth equal to the control in some wells containing flucytosine at concentrations higher than the MIC value was often observed and this phenomenon was in agreement with the growth of several macrocolonies within a clear inhibition ellipse obtained with the $\mathrm{E}$ test. This was due to a high frequency of resistant mutants within a susceptible population.

This study describes the epidemiology of colonization due to C. pelliculosa in several wards, particularly in ICUs, of the IRCCS, Ospedale Maggiore di Milano. From the results of this investigation, two important features emerge: (i) a decreased susceptibility to azole compounds, which supports amphotericin B as the drug of choice; and (ii) a possible clonal origin of the colonization. As deep-seated infections due to C. pelliculosa, either as single cases or as outbreaks, have been reported, further studies should be addressed to identify the possible source of this species in order to prevent colonization and deep infections in the future.

\section{ACKNOWLEDGEMENTS}

This work was supported in part by grants from Ministero Università Ricerca Scientifica Tecnologica (cofin 2000) and from Istituto Superiore di Sanità, Rome, Italy (IV AIDS project, contract no. 50D.29).

\section{REFERENCES}

Alter, S. J. \& Farley, J. (1994). Development of Hansenula anomala infection in a child receiving fluconazole therapy. Pediatr Infect Dis J 13, 158-159.

Barchiesi, F., Hollis, R. J., McGough, D. A., Scalise, G., Rinaldi, M. G. \& Pfaller, M. A. (1995). DNA subtypes and fluconazole susceptibilities of Candida albicans isolates from the oral cavities of patients with AIDS. Clin Infect Dis 20, 634-640.

Barchiesi, F., Torturano, A. M., Falconi Di Francesco, L., Cogliati, M., Scalise, G. \& Viviani, M. A. (1999). In-vitro activity of five antifungal agents against uncommon clinical isolates of Candida spp. J Antimicrob Chemother 43, 295-299.

Goss, G., Grigg, A., Rathbone, P. \& Slavin, M. (1994). Hansenula anomala infection after bone marrow transplantation. Bone Marrow Transplant 14, 995-997.
Haron, E., Anaissie, E., Dumphy, F., McCredie, K. \& Fainstein, V. (1988). Hansenula anomala fungemia. Rev Infect Dis 10, 1182-1186.

Hazen, K. C. (1995). New and emerging yeast pathogens. Clin Microbiol Rev 8, 462-478.

Hirasaki, S., ljichi, T., Fujita, N., Araki, S., Gotoh, H. \& Nakagawa, M. (1992). Fungemia caused by Hansenula anomala: successful treatment with fluconazole. Intern Med 31, 622-624.

Klein, A. S., Tortora, G. T., Malowitz, R. \& Greene, W. H. (1988). Hansenula anomala: a new fungal pathogen. Two case reports and a review of the literature. Arch Intern Med 148, 1210-1213.

Kunova, A., Spanik, S., Kollar, T. \& Krcmery, V., Jr (1996). Breakthrough fungemia due to Hansenula anomala in a leukemia patient successfully treated with amphotericin B. J Chemother 8, 85-86.

Kwon-Chung, K. J. \& Bennett, J. E. (1992). Candidiasis. In Medical Mycology, pp. 280-336. Edited by K. J. Kwon-Chung \& J. E. Bennett. Philadelphia: Lea \& Febiger.

Lehmann, P. F., Lin, D. \& Lasker, D. A. (1992). Genotypic identification and characterization of species and strains within the genus Candida by using random amplified polymorphic DNA. J Clin Microbiol 30, 32493254 .

Munoz, P., Garcia-Leoni, M. E., Berenguer, J., Bernaldo-de-Quiros, J. C. \& Bouza, E. (1989). Catheter-related fungemia by Hansenula anomala. Arch Intern Med 149, 709-713.

Murphy, N., Buchanan, C. R., Damjanovic, V., Whitaker, R., Hart, C. A. \& Cooke, R. W. (1986). Infection and colonisation of neonates by Hansenula anomala. Lancet i, 291-293.

NCCLS (2002). Reference method for broth dilution antifungal susceptibility testing of yeasts. Approved standard M27-A2, Wayne, PA: National Committee for Clinical Laboratory Standards.

Neumeister, B., Rockemann, M. \& Marre, R. (1992). Fungaemia due to Candida pelliculosa in a case of acute pancreatitis. Mycoses 35, 309-310.

Nohinek, B., Zee-Cheng, C. S., Barnes, W. G., Dall, L. \& Gibbs, H. R. (1987). Infective endocarditis of a bicuspid aortic valve caused by Hansenula anomala. Am J Med 82, 165-168.

Pfaller, M. A. (1994). Epidemiology and control of fungal infections. Clin Infect Dis 19 (Suppl. 1), S8-S13.

Qadri, S. M., Al-Dayel, F., Strampfer, M. J. \& Cunha, B. A. (1988). Urinary tract infection caused by Hansenula anomala. Mycopathologia 104, 99-101.

Salesa, R., Burgos, A., Fernandez-Mazarrasa, C., Quindos, G. \& Ponton, J. (1991). Transient fungaemia due to Candida pelliculosa in a patient with AIDS. Mycoses 34, 327-329.

Scherer, S. \& Stevens, D. A. (1987). Application of DNA typing methods to epidemiology and taxonomy of Candida species. J Clin Microbiol 25, 675-679.

Sekhon, A. S., Kowalewska-Grochowska, K., Garg, A. K. \& Vaudry, W. (1992). Hansenula anomala fungemia in an infant with gastric and cardiac complications with a review of the literature. Eur J Epidemiol 8, 305-308

Sneath, P. H. A. (1973). Numerical taxonomy. In The Principle and Practice of Numerical Classification, pp. 230-234. Edited by P. H. A. Sneath \& R. R. Sokal. San Francisco: W. H. Freeman.

Taylor, G. D., Buchanan-Chell, M., Kirkland, T., McKenzie, M. \& Wiens, R. (1994). Trends and sources of nosocomial fungaemia. Mycoses 37, 187-190.

Thuler, L. C., Faivichenco, S., Velasco, E., Martins, C. A., Nascimento, C. R. \& Castilho, I. A. (1997). Fungaemia caused by Hansenula anomala - an outbreak in a cancer hospital. Mycoses 40, 193-196.

van Belkum, A., Melchers, W., de Pauw, B. E., Scherer, S., Quint, W. \& 
Meis, J. F. (1994). Genotypic characterization of sequential Candida albicans isolates from fluconazole-treated neutropenic patients. J Infect Dis $169,1062-1070$.
Vassart, G., Georges, M., Monsieur, R., Brocas, H., Lequarre, A. S. \& Christopher, D. (1985). A sequence in M13 phage detects hypervariable minisatellites in humans and animal DNA. Science 235, 683-684. 